Revista Eletrônica de Direito Processual - REDP.

Rio de Janeiro. Ano 13. Volume 20. Número 1. Janeiro a Abril de 2019

Periódico Quadrimestral da Pós-Graduação Stricto Sensu em Direito Processual da UERJ

Patrono: José Carlos Barbosa Moreira (in mem.). ISSN 1982-7636. pp. 55-81

www.redp.uerj.br

\title{
A ILICITUDE PROBATÓRIA RESULTANTE DA VULNERAÇÃO DO DEVIDO \\ PROCESSO PENAL E A CONSTANTE BUSCA PELA "EFICIÊNCIA" \\ PROCESSUAL ${ }^{1}$
}

THE PROBATING ILLICITITY RESULTING FROM THE VULNERATION OF THE

DUE PENAL PROCESS AND THE CONSTANT SEARCH FOR THE

"EFFICIENCY" PROCESS

Carlos Helder Carvalho Furtado Mendes

Doutorando e Mestre em Ciências Criminais Pela PUCRS.

Pós-Graduado em Direito Penal Econômico pela

Universidade de Coimbra/Ibccrim. Pós-Graduado em

Ciências Penais pela Universidade Anhanguera/Uniderp. São

Luís/MA. E-mail: carloshmendes@gmail.com

Daniel Kessler De Oliveira

Doutorando e Mestre em Ciências Criminais pela PUCRS.

Professor da Universidade Feevale, Nova Hamburgo/RS. Email: danielkessleradv@gmail.com

RESUMO: A produção probatória é marca essencial em um processo penal e seus regramentos, bem como suas finalidades, variam de acordo com o modelo processual vigente e, principalmente, pela forma de conceber o processo. Em um processo pautado pela legalidade e amparado nos ditames constitucionais e convencionais as formas processuais adquirem status de garantias fundamentais e, portanto, não podem sofrer relativizações ainda que em nome de argumentações eficientistas e utilitaristas.

PALAVRAS-CHAVE: Processo Penal; Prova Ilícita; Devido Processo Legal; Eficiência Processual.

\footnotetext{
${ }^{1}$ Artigo recebido em 26/05/2018 e aprovado em 20/11/2018.
} 
Revista Eletrônica de Direito Processual - REDP.

Rio de Janeiro. Ano 13. Volume 20. Número 1. Janeiro a Abril de 2019

Periódico Quadrimestral da Pós-Graduação Stricto Sensu em Direito Processual da UERJ

Patrono: José Carlos Barbosa Moreira (in mem.). ISSN 1982-7636. pp. 55-81

www.redp.uerj.br

ABSTRACT: The probability of production is essential in a criminal proceeding and its regulations, as well as its purposes, vary according to the current procedural model and, mainly, the way of designing the process. In a process ruled by legality and supported by constitutional and conventional dictates as procedural forms they acquire the status of fundamental guarantees and, therefore, can't undergo relativizations even in the name of efficient and utilitarian arguments.

KEYWORDS: Criminal proceedings; Unlawful evidence; Legal due process; Efficiency of the process

SUMÁRIO: Introdução; 1 Ilicitude Probatória e o Processo Penal brasileiro; 2 O Devido Processo Legal (Penal) como Direito Fundamental; 3 Mais uma vez o golpe de cena: a constante busca pela "eficiência” processual penal; Considerações Finais; Referências

\section{INTRODUÇÃO}

Em uma sociedade hiperacelerada, os anseios sociais são por medidas céleres e neste aspecto o tempo processual não é devidamente compreendido e, muito menos, respeitado. Nesta perspectiva, as garantias processuais são entendidas como entraves ao alcance de um desfecho condenatório, popularmente vendido como "justiça". Esta visão eficientista despreza formas, ignora limites e insere-se num quadro de atuação que não dialoga com os preceitos basilares de uma estruturação democrática de processo penal.

Compreender o processo como um mecanismo de defesa de direitos individuais, imprescindíveis para um modelo democrático de atuação estatal é fundamental para que as formas processuais sejam devidamente concebidas. Nisto se insere o direito ao devido processo legal como uma garantia fundamental, cuja a observância é um condicionante da validade da atuação estatal.

Entretanto, seguidamente práticas ilegais são justificadas sob amparo das mais variadas alegações que tergiversam na aplicação dos dispositivos legais e se amparam em pseudo-fundamentos que não são alcançáveis pelos limites da tradicional e adequada aplicação da lei. 
Revista Eletrônica de Direito Processual - REDP.

Rio de Janeiro. Ano 13. Volume 20. Número 1. Janeiro a Abril de 2019

Periódico Quadrimestral da Pós-Graduação Stricto Sensu em Direito Processual da UERJ

Patrono: José Carlos Barbosa Moreira (in mem.). ISSN 1982-7636. pp. 55-81

www.redp.uerj.br

São os mitos justificantes do agir indevido que ainda habitam a prática judicial e doutrinária no campo da ilicitude probatória.

O mito seria aquilo inexplicável racionalmente, aquilo que não podemos ou não queremos explicar com argumentos racionais. Entretanto, como adverte Rubens Casara, "a crença antecede o mito: só há mito porque antes existiu a fé da coletividade"². Ou seja, é necessário que muitos acreditem no mito, que ele venha imbuído por uma crença coletiva na sua existência e importância. E segue, o mesmo autor ao afirmar que "no processo penal brasileiro, o mito atua na recriação de um ambiente autoritário, em contrariedade às promessas da Constituição de 1988"3.

São os mitos da impunidade, da verdade real, da imparcialidade, do utilitarismo processual, dentre tantos outros que legitimam práticas processuais penais indevidas, ilegais e, portanto, ilícitas.

Avaliar criticamente estes aspectos é dever de todos aqueles que pretendem pensar o processo penal amparado em suas bases democráticas e seu papel em um Estado de Direito.

Pode-se ir além, exigindo a constitucionalidade e convencionalidade deste Estado, mas, primeiro, deve-se buscar que ele seja de Direito, isto é, que atue amparado na legalidade.

Como bem leciona Rui Cunha Martins:

Quando se diz, contemporaneamente, que o Estado de Direito está sitiado, ou que ele foi já tomado de assalto pelos grandes interesses; quando, do mesmo modo, se denuncia a conciliação, no seu seio, entre um garantismo de referência e um anti-garantismo populista; quando se lhe imputa o acolhimento na sua órbita doutrinária, de argumentos eficientistas arremessados sobre o processo judicial em prol da celeridade ou da transação penal, resultado de uma desconexão entre o produto moderno que ele é e as contingências de uma atualidade que ele não logra entender e que portanto lhe adulteram o espírito e a vocação; quando assim acontece, pois,

\footnotetext{
${ }^{2}$ CASARA, Rubens R.R. Mitologia Processual Penal. São Paulo: Saraiva, 2015. p, 34.

${ }^{3}$ Id. p, 141.
} 
Revista Eletrônica de Direito Processual - REDP.

Rio de Janeiro. Ano 13. Volume 20. Número 1. Janeiro a Abril de 2019

Periódico Quadrimestral da Pós-Graduação Stricto Sensu em Direito Processual da UERJ

Patrono: José Carlos Barbosa Moreira (in mem.). ISSN 1982-7636. pp. 55-81

www.redp.uerj.br

aquilo que se está a fazer é definir o Estado de direito enquanto

próximo cadáver ${ }^{4}$.

Como defesa do Estado de Direito é que se precisa compreender a problemática da ilicitude de prova.

\section{ILICITUDE PROBATÓRIA E O PROCESSO PENAL BRASILEIRO}

A partir da obra da Prof. Teresa Armenta Deu intitulada "A prova ilícita" é possível perceber que existem diversas concepções sobre a ilicitude em matéria da prova penal. As diversas variações surgem a partir da tradição jurídica dos países da common law e civil law.

Estes, denominados como Continentais, se caracterizam pela conexão da doutrina sobre a ilicitude probatória com a busca da verdade, a aplicação do princípio da legalidade e pela tensão existente, entre aquilo que a autora irá chamar de "diversos fins essenciais da sociedade" (persecução dos delitos ou proteção dos direitos individuais) ${ }^{5}$.

Aqueles, cuja doutrina da ilicitude probatória decorre de fundamento constitucional (4 $4^{\text {a. }} 5^{\text {a }} ; 6$; e $14^{\text {a }}$ Emendas), voltam-se para a proteção de direitos individuais na medida em que o objetivo principal é a imposição de restrições às autoridades dos agentes públicos (função pedagógica) face a seus abusos ou violações de direitos ${ }^{6}$.

Além da variabilidade de configuração e conceito acerca da "prova ilícita", falta uma uniformidade no tratamento relacionado às proibições probatórias. A prova ilícita poderá ter diferentes causas, produzir-se em diferentes momentos e consistir-se em atuações de diferentes sujeitos.

Essa variabilidade, segundo Armenta Deu ${ }^{7}$, está umbilicalmente ligada à tensão entre a tutela de bens essências para a sociedade e garantias processuais, ora na tentativa de restringir os direitos fundamentais, ora para adotar medidas necessárias para alcançar tais garantias exigidas no processo.

\footnotetext{
${ }^{4}$ MARTINS, Rui Cunha. A Hora dos Cadáveres Adiados: Corrupção, Expectativa e Processo. São Paulo: Atlas, 2013. p, 12.

${ }^{5}$ ARMENTA DEU, Teresa. A prova ilícita. 1 ed. São Paulo: Marcial Pons, 2014. p, 25.

${ }^{6}$ Id. p, 37.

${ }^{7}$ Id. p, $64-67$.
} 
Revista Eletrônica de Direito Processual - REDP.

Rio de Janeiro. Ano 13. Volume 20. Número 1. Janeiro a Abril de 2019

Periódico Quadrimestral da Pós-Graduação Stricto Sensu em Direito Processual da UERJ

Patrono: José Carlos Barbosa Moreira (in mem.). ISSN 1982-7636. pp. 55-81

www.redp.uerj.br

De acordo com a autora, a influência midiática pendular sob a percepção da falta de segurança pública, ou quando existe uma maior incidência que atente para a necessidade de preservação das garantias individuais, é um fenômeno definitivamente influenciador na doutrina da ilicitude probatória.

Na semântica processual penal, a palavra prova "passou a representar tudo o que a ela pertine, ou seja, os meios empregados na demonstração dos fatos thema probandum, a atividade utilizada pelas partes para levar ao processo os meios de prova, bem como o próprio resultado do procedimento probatório, ou seja, o convencimento exteriorizado pelo julgador" $"$.

Sendo o processo penal um importante instrumento político ou como definiu Goldschmidt ${ }^{9}$, um termômetro que mede o grau de civilização de uma sociedade e tendo a prova fundamental relevância no desenvolvimento deste instrumento, imprescindível que se compreenda e se estruture as práticas probatórias em conformidade com as aspirações democráticas que regem a legislação processual penal.

Como nos ensina Ruth Gauer, direito (processual penal) está envolto em uma perene questão de prova, visto que, pelo seu imanente caráter histórico-(re)construtivo, almeja sempre desvelar a "verdade" acerca do fato delitivo ocorrido. ${ }^{10}$

A própria finalidade da prova precisa ser devidamente estabelecida, pois irá influenciar sobremaneira as expectativas em torno dos atores judiciais e do próprio instrumento processual penal.

Em uma lógica amparada nas matrizes inquisitoriais que colocam o julgador como ente supremo do processo e que aspiram a revelação da verdade real como objetivo do processo, a prova terá uma finalidade distinta daquela que se verifica ao conceber o processo como um caminho necessário para se chegar, legitimamente, à uma pena ${ }^{11}$, onde

\footnotetext{
${ }^{8}$ GIACOMOLLI, Nereu. O devido processo penal: abordagem conforme a Constituição Federal e o Pacto de São José da Costa Rica. $2^{\mathrm{a}}$ ed. São Paulo: Atlas, 2015. p, 172.

${ }^{9}$ GOLDSCHIDT, afirmou que A estrutura do processo penal de uma nação nada mais é do que termômetro dos elementos corporativos ou autoritários de sua constituição. In GOLDSCHIMIDT, James Paul. Princípios gerais do processo penal, Tradução: Hiltomar Martins de Oliveira. Belo Horizonte: Líder, 2002. p, 71

${ }^{10}$ GAUER, Ruth Maria Chittó. Conhecimento e aceleração (mito, verdade, tempo). In: GAUER, Ruth Maria Chittó (Org.). A Qualidade do Tempo: para além das aparências históricas. Rio de Janeiro: Lumen Juris, 2004. p, 01.

${ }^{11}$ LOPES JR., Aury. Direito processual penal e sua conformidade constitucional. Volume 1. $3^{\mathrm{a}}$ Edição. Rio de Janeiro: Editora Lumen Juris, 2008. p, 9.
} 
Revista Eletrônica de Direito Processual - REDP.

Rio de Janeiro. Ano 13. Volume 20. Número 1. Janeiro a Abril de 2019

Periódico Quadrimestral da Pós-Graduação Stricto Sensu em Direito Processual da UERJ

Patrono: José Carlos Barbosa Moreira (in mem.). ISSN 1982-7636. pp. 55-81

www.redp.uerj.br

as partes atuem em paridade de condições e o julgador é um terceiro imparcial alheio aos interesses da causa.

A tradição inquisitorial é marca indelével de nossa legislação e de nossa prática forense, o que explica uma série de crenças inabaláveis no protagonismo judicial, na busca pela verdade, na ausência de contaminações capazes de afetar a imparcialidade do julgador, dentre outras.

Com isto, o regramento probatório é marcado por esta compreensão, que enxerga na prova um meio capaz de revelar a verdade real e, por isto, limites e restrições ao exercício probatório não são bem aceitos, tampouco compreendidos.

Através desta concepção, advém uma percepção do processo como característica de promessa de uma prestação jurisdicional perfeita, oferecida por um juiz infalível, que irá dizer a verdade e fazer a justiça. Há, assim, uma proximidade muito grande entre esta concepção da verdade e o exercício de um poder arbitrário que desconhece, ou ao menos desrespeita, limites ${ }^{12}$.

A ilicitude probatória cede diante de um anseio maior, de algo mais "nobre", de se revelar a verdade e fazer a justiça, o julgador que se imbui neste espírito, traduz, invariavelmente, aquele modelo trazido por Cordero, para quem "a análise introspectiva exercida por este juiz, rechaça vínculos e formas, exigindo tempo prolongado, penumbras, palavras insinuantes, armadilhas, em um quadro fático indefinidamente variável"13.

O princípio da verdade real, como se vê, funciona como autorização para o juiz "tratar de conseguir" confirmar a hipótese retratada na acusação em defesa da sociedade ${ }^{14}$.

Ademais, a marca cultural será componente vital, na medida em que é do julgador o papel de garante dos direitos fundamentais e das regras do jogo processual, resultando o paradoxo que nos fala Amilton Bueno de Carvalho, onde é o juiz quem controla o próprio sistema de garantias que visa proteger o cidadão do arbítrio do próprio juiz ${ }^{15}$.

A legislação processual penal brasileira em vigor é marcada de forma significativa por esta cultura, bastando uma mera leitura em nossos dispositivos legais, bem como uma

\footnotetext{
12 KHAled JR., Salah Hassan A Busca da Verdade no Processo Penal: Para Além da Ambição Inquisitorial. São Paulo: Atlas, 2013. p, 494.

${ }^{13}$ CORDERO, Franco. Procedimiento Penal. Trad. Jorge Guerrero. Editorial Temis: Santa Fe de Bogotá, 2000. p, 24

${ }^{14}$ CASARA, Rubens R.R. Mitologia Processual Penal. São Paulo: Saraiva, 2015. p, 166.

${ }^{15}$ CARVALHO, Amilton Bueno de. Eles, os juízes criminais, vistos por nós, os juízes criminais. Rio de janeiro: Lumen Juris, 2011. p, 44
} 
Revista Eletrônica de Direito Processual - REDP.

Rio de Janeiro. Ano 13. Volume 20. Número 1. Janeiro a Abril de 2019

Periódico Quadrimestral da Pós-Graduação Stricto Sensu em Direito Processual da UERJ

Patrono: José Carlos Barbosa Moreira (in mem.). ISSN 1982-7636. pp. 55-81

www.redp.uerj.br

simples pesquisa jurisprudencial e, até mesmo, uma consulta aos doutrinadores mais utilizados para que se possa verificar às claras a influência desta compreensão.

Para que possamos falar em ilicitude probatória, precisamos refletir sobre esta cultura e sobre as finalidades da prova e do próprio processo penal.

Como poderemos enfrentar o tema na sua completude sem nos debruçarmos sobre a cultura que está por de trás de sua compreensão? É árdua a tarefa de colocar o tema da ilicitude probatória em consonância com os ideais constitucionais e convencionais, quando em nossa legislação, as nulidades foram concebidas como um "meandro técnico por onde se escoa a substância do processo e se perdem o tempo e a gravidade da justiça"16.

Desde sua fascista gênese, o Código de Processo Penal Brasileiro de 1941 carrega em seu âmago, como marca ideológica indelével, a louca vontade de "trazer o bem" e "extirpar o mal". Tal qual a kafkiana Máquina Penal, ainda hoje - em terreno sedizente democrático - o processo faz uso "de elementos provenientes do patrimônio ditatorial" e, mais do que nunca, torna-se um engenhoso mecanismo destinado a fazer sofrer réus em prol do bem comum ${ }^{17}$.

A supremacia do interesse comum faz com que as formas processuais sejam distorcidas e as garantias flexibilizadas e o pior, amparados em pseudo-argumentos salvacionistas.

Entretanto, todas estas práticas não resistem a uma filtragem constitucional, que exige do processo penal um outro papel em uma estruturação democrática de Estado, como adverte Rubens Casara, "A função primordial do processo penal é limitar (racionalizar) o poder punitivo estatal e não potencializá-lo em nome do direito abstrato à segurança pública" 18 .

Portanto, a busca do julgador não é pela verdade, a própria prática probatória se submete ao princípio de legalidade e não se busca uma verdade absoluta, mas sim aquela que determinam as partes $^{19}$.

\footnotetext{
${ }^{16}$ BRASIL, Exposição de Motivos ao Código de Processo Penal Brasileiro.

${ }^{17}$ MARTINS, Rui Cunha. O Ponto Cego do Direito, The Brazilian Lessons. Rio de Janeiro: Lumen Juris, 2010. p. 112-114.

${ }^{18}$ CASARA, Rubens R.R. Mitologia Processual Penal. São Paulo: Saraiva, 2015. P: 142.

${ }^{19}$ ARMENTA DEU, Teresa. Sistemas Procesales Penales. La justicia penal em Europa y America. Madrid: Marcial Pons, 2012. P. 91
} 
Revista Eletrônica de Direito Processual - REDP.

Rio de Janeiro. Ano 13. Volume 20. Número 1. Janeiro a Abril de 2019

Periódico Quadrimestral da Pós-Graduação Stricto Sensu em Direito Processual da UERJ

Patrono: José Carlos Barbosa Moreira (in mem.). ISSN 1982-7636. pp. 55-81

www.redp.uerj.br

Não há nenhuma constituição democrática que não pressuponha a existência de direitos individuais, que não parta da ideia de que em um primeiro momento vem a liberdade dos cidadãos e só depois o poder do governo, que os cidadãos constituem e controlam através de suas liberdades ${ }^{20}$.

Uma das promessas normativas das primeiras democracias modernas, foi a de que os cidadãos teriam respeitados os seus direitos, o que pressupõe a presença de uma comunidade politicamente organizada e normatizada institucionalmente pelo estado $^{21}$, daí a importância de se ter limites claros para atuação estatal em matéria processual, no qual se insere com especial relevância a prática probatória.

Assim, em um sistema amparado nas disposições democráticas de nossa Constituição, a finalidade da prova é formar o convencimento do julgador e daí nascem regras e princípios processuais que limitam a atividade das partes para esse propósito.

Conforme Eberhardt ${ }^{22}$, o sistema de provas adotado pelo Código de Processo Penal brasileiro é o liberatório. Significa dizer que às partes é permitida a busca probatória além do rol de possibilidades estabelecido em lei, desde que sejam provas lícitas. O direito à prova não é absoluto e seus limites são encontrados na norma convencional, constitucional e ordinária ${ }^{23}$.

Todavia, a ausência de um regramento claro da sistematização probatória no Código de Processo Penal, 1941, é o retrato da essência inquisitorial do processo penal brasileiro, principalmente por não haver limites claros quanto à admissibilidade de meios de $\operatorname{prova}^{24}$.

Giacomolli ${ }^{25}$ esclarece que "esse perfil inquisitorial permite a admissibilidade de qualquer meio de prova e a validade de qualquer metodologia empregada, na medida em que, para esse modelo político e jurídico de processo, tudo é possível para se chegar à

\footnotetext{
${ }^{20}$ BOBBIO, Norberto. A era dos direitos. Tradução de Carlos Nelson Coutinho. Rio de Janeiro: Elsevier, 2004. P.130.

${ }^{21}$ GAUER, Ruth Maria Chitto. Constituição e Cidadania. Porto Alegre: Livraria do Advogado, 2014. p, 21.

${ }^{22}$ EBERHARDT, Marcos. Provas no processo penal: análise crítica, doutrinária e jurisprudencial. Porto Alegre: Livraria do Advogado Editora, 2016. p, 52.

${ }^{23}$ GIACOMOLLI, Nereu. O devido processo penal: abordagem conforme a Constituição Federal e o Pacto de São José da Costa Rica. Op. Cit. p, 177.

${ }^{24}$ GIACOMOLLI, Nereu. Reformas (?) do processo penal: considerações críticas. Rio de Janeiro: Editora Lumen Juris. 2008. p, 5.

${ }^{25}$ Id. p, 9.
} 
Revista Eletrônica de Direito Processual - REDP.

Rio de Janeiro. Ano 13. Volume 20. Número 1. Janeiro a Abril de 2019

Periódico Quadrimestral da Pós-Graduação Stricto Sensu em Direito Processual da UERJ

Patrono: José Carlos Barbosa Moreira (in mem.). ISSN 1982-7636. pp. 55-81

www.redp.uerj.br

"verdade material", mesmo pelos caminhos da ilicitude, vedada expressamente pela Constituição Federal (art. 5, LVI, CF)".

A definição de ilicitude da prova, era acentuada por parte da doutrina como aquela que decorre da colheita de prova com infração a normas ou princípios de direito material, como exemplo: os direitos constitucionalmente garantidos, o direito à intimidade, à liberdade, à dignidade humana.

No Brasil, a distinção proposta pela doutrina de Ada Pellegrini Grinover, com base em Nuvolone, era de que seriam espécies do gênero prova ilegal, a prova ilícita e ilegítima $^{26}$. A segunda espécie, nomeada prova ilegítima, fazia referência àquelas que a metodologia de sua produção ou obtenção violavam as normas processuais.

Esta distinção - inicialmente -, conforme salienta Badaró ${ }^{27}$, acarretava em uma diferenciação de sanções. Casos em que violada uma norma material haveria uma sanção de direito material, a seu turno, nos casos em que houvesse sido desrespeitada uma norma processual, haveria apenas uma sanção processual. Em outras palavras "não havia sanção processual para a violação da regra de direito material"28.

A partir da Constituição de 1988, o tratamento para a ilicitude probatória se daria tanto em termos de sanções de direito material, como por sanções de direito processual ${ }^{29}$.

Lê-se a Constituição pelo Código Penal e Processual Penal, quando, na verdade, deveria ser justamente o contrário. Apegados à legalidade mal-entendida, ou seja, a um legalismo pedestre, muitos campos do Direito, mormente o processual penal, não fizeram a devida oxigenação constitucional ${ }^{30}$.

No entanto, a partir da redação ditada pelo art. 157 do Código de Processo Penal, após a reforma de 2008, não se consegue enxergar a necessidade da distinção que se fazia anteriormente entre ilegitimidade e ilicitude no que tange às provas. Aliás, de acordo com

\footnotetext{
${ }^{26}$ BADARO, Gustavo. Processo penal. $4^{\mathrm{a}}$ ed. rev. atual. e ampl. São Paulo: Editora Revista dos Tribunais, 2016. p, 405.

${ }^{27}$ Id. p, 406.

${ }^{28}$ Id. Ibidem.

${ }^{29}$ Id. Ibidem,

${ }^{30}$ ROSA, Alexandre Morais da. Guia Compacto do Processo Penal conforme a Teoria dos Jogos. 1 Ed. Rio de Janeiro: Lumen Juris, 2013. P. 80
} 
Revista Eletrônica de Direito Processual - REDP.

Rio de Janeiro. Ano 13. Volume 20. Número 1. Janeiro a Abril de 2019

Periódico Quadrimestral da Pós-Graduação Stricto Sensu em Direito Processual da UERJ

Patrono: José Carlos Barbosa Moreira (in mem.). ISSN 1982-7636. pp. 55-81

www.redp.uerj.br

Armenta Deu $^{31}$, tal dispositivo determina a inadmissibilidade e a consequente exclusão da prova tida por ilícita.

Dispõe o referido artigo que "são inadmissíveis, devendo ser desentranhadas do processo, as provas ilícitas, assim, entendidas as obtidas em violação a normas constitucionais ou legais". Desta forma, Badaró ${ }^{32}$ conceitua as provas ilícitas como aquelas obtidas, admitidas ou produzidas com violação das garantias constitucionais, sejam as que asseguram liberdades públicas, sejam as que estabelecem garantias processuais. Neste ponto o devido processo penal.

Há que ressaltar o pensamento de Armenta Deu, no qual o único meio de flexibilizar a presunção de inocência é a prova legal, portanto, a licitude da prova liga-se essencialmente ao princípio da legalidade. O fundamento da prova ilícita, muito mais além do que depender da adoção de determinado sistema jurídico (civil law ou common law) obedece às circunstâncias as quais em maior ou menor escala preservam determinadas garantias, necessariamente, atendendo a um devido processo (justo processo; ou ao fairness process) $)^{33}$.

$\mathrm{Na}$ medida em que o Código de Processo Penal brasileiro não infere nenhuma regra de taxatividade, como antes exposto, a limitação dar-se-á pelas regras ordinárias, constitucionais e convencionais. Destaca Giacomolli ${ }^{34}$ que a depender do grau invasividade da metodologia da produção da prova, necessário exigir-se a reserva legal.

Quanto ao regime probatório instituído em um processo penal democrático, evidente que este compõe o sistema de garantias e sob o aspecto de que "fixa os limites para a coleta e busca da informação que nutrirá o processo de verificação ou processo cognitivo",35.

Como refere Arnaldo Miglino, “a Democracia é hoje, sobretudo, um sistema de controle de poder, quanto mais eficaz for esse controle muito mais poderão ser atuados os

\footnotetext{
${ }^{31}$ ARMENTA DEU, Teresa. A prova ilícita: um estudo comparado. 1. ed. São Paulo: Marcial Pons, 2014, p. 39.

${ }^{32}$ BADARO, Gustavo. Processo penal. Op. Cit. p, 412.

${ }^{33}$ ARMENTA DEU, Teresa. A prova ilícita: um estudo comparado. Op. Cit. p, 177.

${ }^{34}$ GIACOMOLLI, Nereu. O devido processo penal. Op cit. p, 178.

35 BINDER, Alberto M. O Descumprimento das formas processuais: elementos para uma crítica da teoria unitária das nulidades no processo penal. Rio de Janeiro: Editora Lumen Juris, 2003. p, 61.
} 
Revista Eletrônica de Direito Processual - REDP.

Rio de Janeiro. Ano 13. Volume 20. Número 1. Janeiro a Abril de 2019

Periódico Quadrimestral da Pós-Graduação Stricto Sensu em Direito Processual da UERJ

Patrono: José Carlos Barbosa Moreira (in mem.). ISSN 1982-7636. pp. 55-81

www.redp.uerj.br

princípios democráticos essenciais, comuns à democracia grega e à moderna" ${ }^{36}$. E conclui

o autor que: "a democracia se caracteriza por regras que estabelecem procedimentos, pelas quais se estabelece quem e como controla a comunidade" 37 .

Binder é cristalino ao afirmar que as regras probatórias no processo penal limitam a aquisição de informações. Apesar da existência de uma norma genérica que permite utilizar meios de provas distintos dos previstos, o regime probatório destina a tais meios de prova as formalidades análogas daqueles permitidos legalmente. Não é possível o ingresso de informações em juízo por vias que não são previstas em lei ${ }^{38}$.

Afirma o autor que apesar de tudo, a possibilidade de distorção e manipulação não foram evitadas simplesmente com sua determinação legal. Desta forma, novos limites foram construídos, como a necessidade de autorização judicial expressa ou procedimentos com requisitos especiais, ou ainda outras formas de impor limites (horários, pessoas que podem realizar registros e etc) $)^{39}$.

Não é demais repetir que em um Estado de Direito, abrir mão da (busca inalcançável da) "verdade", além de fundamentalmente prudente, é sacrifício mais que necessário para evitar o abuso de poder do Estado $^{40}$.

Por isto a forma processual deve ser compreendida neste aspecto, como já dito, com uma tarefe de limitar poderes, pois como assevera Zaffaroni: "a mais elementar experiência institucional demonstra que sempre que há poder sem controle opera-se o abuso de poder" ${ }^{\prime 1}$.

Neste ponto se insere o Poder Judiciário, responsável pela árdua tarefa de contrapor normas ordinárias às constitucionais (e porque não se referir a compatibilização de princípios) quando se depara frente a uma norma arbitrária. Como pontua Prado $^{42}$ as decisões jurídicas não são politicamente neutras, há sempre uma política que se manifesta,

\footnotetext{
${ }^{36}$ MIGLINO, Arnaldo. As Cores da Democracia. Tradução Fauzi Hassan Chouckr. 2a ed. Florianópolis: Empório do Direito, 2016. P: 134.

${ }^{37}$ MIGLINO, Arnaldo. As Cores da Democracia. Tradução Fauzi Hassan Chouckr. 2a ed. Florianópolis: Empório do Direito, 2016. P: 120.

${ }^{38}$ BINDER, Alberto M. O Descumprimento das formas processuais: elementos para uma crítica da teoria unitária das nulidades no processo penal. Rio de Janeiro: Editora Lumen Juris, 2003. p, 65.

${ }^{39}$ Id. ibidem.

${ }^{40}$ Id. p, 67.

${ }^{41}$ ZAFFARONI, Eugênio Raul. Poder Judiciário: Crises, acertos e desacertos. Trad: Juarez Tavares. São Paulo: Revista dos Tribunais, 1995. p, 81.

42 PRADO, Geraldo. Limites às interceptações telefônicas e a jurisprudência do Superior Tribunal de Justiça. $2^{a}$ ed. Rio de Janeiro: Editora Lumen Juris. 2006, p, 10.
} 
Revista Eletrônica de Direito Processual - REDP.

Rio de Janeiro. Ano 13. Volume 20. Número 1. Janeiro a Abril de 2019

Periódico Quadrimestral da Pós-Graduação Stricto Sensu em Direito Processual da UERJ

Patrono: José Carlos Barbosa Moreira (in mem.). ISSN 1982-7636. pp. 55-81

www.redp.uerj.br

todavia esta política em uma república não pode ser uma política qualquer, senão tão somente um política espelhada na Constituição da República, para consagrar válido o ato jurídico.

E tal deve ser o direcionamento de toda análise que pretende observar a imposição de limites a direitos fundamentais, principalmente quando é a própria Constituição Federal que reclama a reserva de lei para a restrição ou suspenção de tais direitos ${ }^{43}$.

Nesta direção, salienta Armenta Deu que, tendo a ilicitude probatória lugar constitucionalizado, como no caso do Brasil, verifica-se um reforço à tutela do risco da vulneração de regras probatórias. A preservação do núcleo do direito determina a legitimidade da condenação ${ }^{44}$. No tocante à restrição de direitos fundamentais é evidente que àqueles restringíveis poder-se-á falar em preservação de seu núcleo essencial.

Todavia, entende-se que não é possível falar em restrição - mínima que seja - do mandado constitucional de proteção ao devido processo. Tem-se o devido processo penal como garantia constitucional irrestringível, pois o resultado da mínima restrição que seja a este, o tornará impossível de ser chamado "devido" processo, pois somente assim o será quando observado em completude. O respeito ao devido processo (penal) equivale ao respeito ao ordenamento jurídico constitucional do Estado de Direito.

Tem-se como meta, portanto, uma "qualidade da decisão penal" somente alcançada quando existe a compatibilização da decisão penal e dos procedimentos probatórios ao Estado de Direito ${ }^{45}$.

Permitir comportamentos pautados em ilicitudes estatais é esquecer que "o processo penal moderno, entendido como característico do Estado de Direito [...], são as proibições probatórias que realmente constituem o núcleo essencial de um processo penal adaptado às exigências do Estado de Direito, não apenas enquanto implica o respeito a determinadas formalidades, garantias e competências que devem ser observadas na tramitação do processo penal, mas também enquanto é dever ser respeitoso com os direitos fundamentais no processo, que constitui um limite que não pode ser franqueado nunca,

\footnotetext{
${ }^{43}$ Id. p, 11.

${ }^{44}$ ARMENTA DEU, Teresa. A prova ilícita. Op. cit. p, 178.

${ }^{45}$ PRADO, Geraldo. Prova penal e sistema de controles epistêmicos: a quebra da cadeia de custódia das provas obtidas por métodos ocultos. 1 ed. São Paulo: Marcial Pons, 2014. p, 39.
} 
Revista Eletrônica de Direito Processual - REDP.

Rio de Janeiro. Ano 13. Volume 20. Número 1. Janeiro a Abril de 2019

Periódico Quadrimestral da Pós-Graduação Stricto Sensu em Direito Processual da UERJ

Patrono: José Carlos Barbosa Moreira (in mem.). ISSN 1982-7636. pp. 55-81

www.redp.uerj.br

nem sequer por causa de uma maior eficácia na busca da verdade, na investigação e persecução do delito" ${ }^{\prime 4}$.

O tratamento à ilicitude probatória, portanto, deverá ocorrer nos moldes em que discorre Badaró ${ }^{47}$, em que os meios obtidos ilicitamente são inadmissíveis no processo e caso ingressarem neste, devem ser desentranhados. Em ambos os casos, jamais podendo ser valorados pelo Julgador.

Aliás, cabe ressaltar a falha legislativa dada pela reforma processual penal de 2008, em que vetou $\S 4^{\circ}$ do artigo 157, no qual era previsto que "o juiz que conhecer do conteúdo da prova declarada inadmissível não poderá proferir a sentença ou acórdão". Somado a isto, assevera Gloeckner ${ }^{48}$ que a vedação constitucional do ingresso no processo penal da prova que vulnera proibições probatórias atinge não apenas direitos fundamentais como a intimidade ou a privacidade, "incide, de igual forma sobre o devido processo penal, também consagrado constitucionalmente".

\section{O DEVIDO PROCESSO LEGAL (PENAL) COMO DIREITO FUNDAMENTAL}

O Due Process of Law é a garantia que o imputado tem da obediência às formalidades processuais, o respeito às regras do jogo. Evitam-se com o devido processo legal, situações semelhantes à narrada por Franz Kafka ${ }^{49}$ em "O Processo", na qual "o comum e o grotesco se imiscuem, compondo uma atmosfera de estranheza e opressão, em que o absurdo toma lugar do cotidiano e é apresentado com a maior naturalidade", evita-se, portanto, que a vergonha sobreviva à pessoa do réu, quando este se situa em um processo desconhecido, ou descabido de forma. E forma é garantia de ausência de arbítrio ${ }^{50}$.

O processo penal, como matéria jurídica, é que dita o trâmite para a aplicação de penas e sanções. O devido processo legal é o direito processual à garantia de isonomia,

\footnotetext{
${ }^{46}$ MUÑOZ CONDE, Francisco. De la prohibición de autoincriminación al derecho procesal penal del enemigo. In: Estudos em homenagem ao Prof. Doutor Jorge de Figueiredo Dias / coord. por Manuel da Costa Andrade, Maria João Antunes, Susana Aires de Sousa, Vol. 3, 2009 (Direito Penal (Cont.)), ISBN 978972-32-1793-3, págs. 1013 - 1040. Boletim da Faculdade de Direito, Stvdia Ivridica 100, Ad Honorem - 5, Universidade de Coimbra, Coimbra Editora. p, 1014.

${ }^{47}$ BADARÓ, Gustavo. Processo Penal. Op. cit. p, 412.

${ }^{48}$ GLOECKNER, Ricardo Jacobsen. Nulidades no processo penal. $2^{\text {a }}$ ed. Editora: Jus Podivm. 2015, p. 504 $-505$.

${ }^{49}$ KAFKA, Franz. O processo. 5. Ed. São Paulo: Martin Claret, 2011.

${ }^{50}$ LOPES JR, Aury. Direito processual penal. Op. cit. p, 154.
} 
Revista Eletrônica de Direito Processual - REDP.

Rio de Janeiro. Ano 13. Volume 20. Número 1. Janeiro a Abril de 2019

Periódico Quadrimestral da Pós-Graduação Stricto Sensu em Direito Processual da UERJ

Patrono: José Carlos Barbosa Moreira (in mem.). ISSN 1982-7636. pp. 55-81

www.redp.uerj.br

presunção de inocência, ampla defesa, contraditório, duplo grau de jurisdição, publicidade, imparcialidade judicial e motivação.

O processo penal é uma garantia do cidadão e, por isso, deve ser devido (devido processo legal). O povo para poder buscar a democracia, deixa como inalienável ao indivíduo, a sua liberdade e o Estado não somente não pode nesta penetrar de forma indevida, como é o seu principal garante, através dos meios pertinentes, como o devido processo legal. ${ }^{51}$

Porém, há que se ultrapassar o caráter meramente legal incorporado pelo processo penal para alcançar seu caráter humanitário e convencional. Como sustenta Giacomolli ${ }^{52}$, "faz-se mister uma nova metodologia hermenêutica (também analítica e linguística), valorativa, comprometida de forma ético-política, dos sujeitos do processo e voltada ao plano internacional de proteção de direitos humanos”.

Refere, ainda, o autor:

Não mais encontram legitimidade o discurso e a argumentação dos juristas e dos sujeitos do processo quando arraigados no paradigma solitário e perfeito do arcabouço ordinário das regras do $\mathrm{CPP}$, de sua validade pelo fato da existência, sem questionamentos constitucionais e convencionais. Portanto, há necessidade de rompimento dessas barreiras, na direção da construção de um processo penal constitucional e humanitário ${ }^{53}$.

Certamente que o desrespeito ao devido processo (constitucional, convencional e humanitário), bem como todas as suas garantias, é uma ofensa ao Estado Democrático de Direito. Como lembra Bernardes ${ }^{54}$, o processo judicial exige funcionamento eficaz, somente possível quando há submissão do juiz à lei processual, "não lhe sendo permitida a

\footnotetext{
${ }^{51}$ COUTINHO, Jacinto Nelson de Miranda. Glosas ao Verdade, Dúvida e Certeza de Francesco Carnelutti para os Operadores do Direito. In: Revista de Estudos Criminais Ano 4 No 14. Sapucaia do Sul: Notadez, 2004. P.90

${ }^{52}$ GIACOMOLLI, Nereu José. O devido processo penal: Abordagem conforme a constituição federal e o pacto de são José da costa rica. Op. cit. p, 12.

${ }^{53}$ Id. p, 14.

${ }^{54}$ BERNARDES, Marcelo Di Rezende. O princípio constitucional da motivação das decisões judiciais. Op. cit, 2013, p. 200.
} 
Revista Eletrônica de Direito Processual - REDP.

Rio de Janeiro. Ano 13. Volume 20. Número 1. Janeiro a Abril de 2019

Periódico Quadrimestral da Pós-Graduação Stricto Sensu em Direito Processual da UERJ

Patrono: José Carlos Barbosa Moreira (in mem.). ISSN 1982-7636. pp. 55-81

www.redp.uerj.br

criação ou modificação de regras de procedimento, tendo em vista que ele não pratica a função em seu próprio nome, mas sim em nome do Estado".

Desta feita, pode-se dizer que o devido processo legal relaciona-se intimamente com o sistema de garantias, com a função de impedir excessos prejudiciais ao polo passivo da demanda processual, que se torna desnivelada quando possui o Estado e todo o seu aparato e instrumentos de persecução penal, como polo ativo.

Uma leitura convencional e constitucional do processo penal, a partir da constitucionalização dos direitos humanos, é um dos pilares a sustentar o processo penal humanitário. ${ }^{55}$

Todos os princípios e garantias fundamentais se misturam a fim de proteger de lesões o indivíduo que responde um processo. Além de garantia, o devido processo legal é uma responsabilidade do Poder Público, devendo este, torná-lo efetivo. Como afirma Pozzebon ${ }^{56}$, "cabe ao juiz não só fiscalizar o respeito a esta garantia, mas também promovê-la de modo a torná-la eficaz".

Ao invocar princípios inerentes à figura do magistrado, tais como sua formação, sua independência funcional, imparcialidade e responsabilidade, evidencia-se que ao magistrado incumbe o serviço de administrar a justiça, que o põe em serviço de todos aqueles que buscam por meio da tutela jurisdicional a defesa de bens jurídicos. Obviamente, que o réu em um processo penal, busca, efetivamente, a defesa de seus direitos mais fundamentais e, certamente, que como imparcial não caberá ao juiz o papel de defensor daquele, mas caberá a este a função de garantidor. Do contrário, voltar-se-á aos tempos desarmônicos, onde não se careceria da presença do Estado na resolução de conflitos sociais.

Como destaca, Aury Lopes Jr:

O fundamento da legitimidade da jurisdição e da independência do Poder Judiciário está no reconhecimento da sua função de garantidor dos direitos fundamentais inseridos ou resultantes da

\footnotetext{
55 GIACOMOLLI, Nereu José. O Devido Processo Penal: abordagem conforme a Constituição Federal e o Pacto de São José da Costa Rica. São Paulo: Atlas, 2014. P: 12.

${ }^{56}$ POZZEBON, Fabrício Dreyer de Avila. O direito fundamental à motivação no processo penal como corolário de outras garantias constitucionais. Direitos Fundamentais e Justiça Nº8. Jul/Set. 2009. p, 152.
} 
Revista Eletrônica de Direito Processual - REDP.

Rio de Janeiro. Ano 13. Volume 20. Número 1. Janeiro a Abril de 2019

Periódico Quadrimestral da Pós-Graduação Stricto Sensu em Direito Processual da UERJ

Patrono: José Carlos Barbosa Moreira (in mem.). ISSN 1982-7636. pp. 55-81

www.redp.uerj.br

Constituição. Nesse contexto, a função do juiz é atuar como garantidor da eficácia do sistema de direitos e garantias fundamentais do acusado no processo penal ${ }^{57}$.

De acordo com Sarlet $^{58}$, direitos fundamentais são todas as posições jurídicas concernentes às pessoas, que, do ponto de vista do direito constitucional positivo, foram, por seu conteúdo e importância integradas ao texto da Constituição e, portanto, retiradas da esfera de disponibilidade.

Assim o fez o constituinte brasileiro, ao dispor no caderno de Direitos e Garantias Fundamentais, da Constituição Federal de 1988. No Art. 5ª LIV, está previsto que ninguém será privado de sua liberdade ou de seus bens sem o devido processo legal.

Nesta senda, o devido processo está marcado no âmbito dos direitos fundamentais de primeira dimensão, pois está concebido especificamente como um direito de defesa, (direito de cunho negativo) "demarcando uma zona de não intervenção do Estado, isto é dirigido a uma abstenção por parte dos poderes públicos e neste sentido, sento um direito de resistência ou de oposição perante o Estado" 59 .

Os direitos fundamentais não se constituem em meras declarações decorativas, em simples exortações programáticas de retórica jurídica, e nem em formalismo político ocasional e oportunista, mas oferecem os pilares ao processo penal, motivo por que possuem aplicação imediata, embora, em certas situações necessitem da densificação ordinária ${ }^{60}$.

\section{MAIS UMA VEZ O GOLPE DE CENA: A CONSTANTE BUSCA PELA "EFICIÊNCIA" PROCESSUAL PENAL}

\footnotetext{
${ }^{57}$ LOPES JR. Direito processual penal. Op. cit, 2014. p, 160.

58 SARLET, Ingo Wolfgang. A eficácia dos direitos fundamentais. 11 ed., revista e atualizada, Porto Alegre: Livraria do Advogado Editora, 2012. p, 77.

59 SARLET, Ingo Wolfgang; MARINONI, Luiz Guilherme; MITIDIERO, Daniel. Curso de Direito Constitucional. $6^{a}$ ed., revista e atualizada. São Paulo: Saraiva, 2017. p, 341.

${ }^{60}$ GIACOMOLLI, Nereu José. O Devido Processo Penal: abordagem conforme a Constituição Federal e o Pacto de São José da Costa Rica. São Paulo: Atlas, 2014. p, 33.
} 
Revista Eletrônica de Direito Processual - REDP.

Rio de Janeiro. Ano 13. Volume 20. Número 1. Janeiro a Abril de 2019

Periódico Quadrimestral da Pós-Graduação Stricto Sensu em Direito Processual da UERJ

Patrono: José Carlos Barbosa Moreira (in mem.). ISSN 1982-7636. pp. 55-81

www.redp.uerj.br

É de se saber que o Processo Penal não se ocupa do combate à criminalidade.

Toda a preocupação em proteger interesses da coletividade contra a violência ${ }^{61}$ que derrama sobre a sociedade o sentimento do medo não deve ser objeto a ser protegido pelo Processo Penal. Em verdade, como já dito, preocupa-se em garantir limites ao poder punitivo do Estado.

Todavia, o ritmo desenfreado da dinâmica social afeta tudo que está inserido nesta sociedade hiper acelerada. O tempo da realidade, nesta dinâmica, se confronta com o tempo do direito; do processo.

Uma visão eficientista e utilitarista do processo penal clama por cada vez mais punição, reduzindo os níveis de observância aos direitos fundamentais.

Isso significa que o aspecto punitivo ganha cada vez mais força no discurso jurídico, reforçando a exigência de uma sanção célere - não importa se violando o direito fundamental. ${ }^{62}$

Ost $^{63}$ avalia que o Estado Social ao levar em consideração este medo que toma centro nas preocupações coletivas e o risco inerente à sociedade, transmuda a natureza e a escala do próprio risco que passa ser considerado inassegurável, uma ameaça absoluta, na qual a única estratégia de combate se dá, absolutamente, pela prevenção.

Porém, prevenir-se de algo desconhecido ou invisível requer tarefa hercúlea. Impõe-se o saber antecipado, a busca do saber como princípio da prevenção, para se precaver diante da gravidade do risco. Hassemer ${ }^{64}$ afirma que essa exigência tem sido satisfeita por reformas penais (materiais e processuais) na luta preventiva contra o delito, na qual se busca eliminar os mais sensíveis limites e garantias constitucionais do Direito (Processual) Penal.

O tempo nesta órbita, dirá Ost ${ }^{65}$, saiu do seu eixo. Não é mais o tempo da lógica duradoura, da expectativa. Do longo prazo passa-se ao curto prazo, e deste ao imediatismo.

\footnotetext{
${ }^{61}$ Violência aqui no sentido limitado e rasteiro concebido na Modernidade à tão somente noção de violência ligada a aspectos criminais. BIZZOTO, Alexandre. A mão invisível do medo e o pensamento criminal libertário. $1^{\mathrm{a}}$ ed. Florianópolis: Empório do Direito. 2015. p, 101.

62 MARRAFON, Marco Aurélio. Constituição e Poder, Vol. 1: decisão constitucional, filosofia da linguagem e direito. $1^{\mathrm{a}}$ ed. Florianópolis: Empório do Direito, 2016. P: 17

${ }^{63}$ OST, François. O tempo do direito. Bauru, SP: Edusc, 2005. p, 323.

${ }^{64}$ HASSEMER, Winfried. El destino de los derechos del ciudadano en un derecho penal eficaz. Estudios Penales y Criminológicos, vol. XV (1992). Cursos e Congresos $n^{o} 71$ Servizo de Publicacións da Universidade de Santiago de Compostela. ISBN 84-7191-866-8, pp. 182-198.p, 189.

${ }^{65}$ OST, François. O tempo do direito. Op. cit. p, 327.
} 
Revista Eletrônica de Direito Processual - REDP.

Rio de Janeiro. Ano 13. Volume 20. Número 1. Janeiro a Abril de 2019

Periódico Quadrimestral da Pós-Graduação Stricto Sensu em Direito Processual da UERJ

Patrono: José Carlos Barbosa Moreira (in mem.). ISSN 1982-7636. pp. 55-81

www.redp.uerj.br

A era do efêmero é portanto característica das sociedades do tempo real, na qual a volatilidade do tempo impera.

A urgência, uma ação imediata, inaugura o combate a estes riscos. Ost ${ }^{66}$ relembra que a situação emergencial que demanda urgência é caso excepcional, em princípio, e nesta até mesmo a violação dos procedimentos ordinários é válida. Esta urgência, ou melhor, Estado de urgência, possui a capacidade - danosa - de produzir um efeito de generalização, ou seja, não há espaço para a expectativa quando busca-se alcançar o objetivo imediato, imediatamente. "A urgência nutre a cultura da impaciência que transforma qualquer prazo em prorrogação insuportável e qualquer transição, por um bloqueio institucional, criticável"67.

Se essa dinâmica social afeta tudo ao seu redor, não seria diferente que em uma hiper-aceleração constante, o direito - e no presente estudo o processo penal - não sofresse com seus efeitos. Coloca-se a evidência sobreposta ao formalismo, nos dizeres de Coutinho $^{68}$, o direito passa a ser acusado de burocrático, considerado um obstáculo e nesta senda a eficiência toma de assalto o lugar da efetividade.

Explica o autor que eficiência quando alinhada ao tempo (ainda mais este demasiadamente acelerado) trata-se de exclusão, ou seja, a supressão de direitos fundamentais e garantias processuais. Flexibilizar garantias fundamentais faz parte da grande onda que afoga o direito processual penal no mar agitado/acelerado da pretensão punitiva.

A ação eficiente transforma um Juiz em um servidor público formato Eichmann que influenciado pela melhor alocação de riquezas em sociedade, aliada ao método custobenefício para as relações humanas, se submete aos princípios da economia, subvertendose, ou melhor, abstendo-se da posição de garante ${ }^{69}$. Reserva-se ao papel neoliberal estratégico com o objetivo de equilibrar o mercado, um servidor exemplar e cumpridor de

\footnotetext{
${ }^{66}$ Id. p, 331.

${ }^{67}$ Id. p, $334-335$.

68 COUTINHO, Jacinto Nelson de Miranda. Efetividade do Processo Penal e Golpe de Cena: um problema às reformas processuais. 2015. Disponível em: http://emporiododireito.com.br/efetividade-doprocesso-penal-e-golpe-de-cena-um-problema-as-reformas-processuais-por-jacinto-nelson-de-mirandacoutinho/. Acesso em Jul 2017.

69 ROSA, Alexandre Morais da e MARCELLINO JR, Julio Cesar. O processo eficiente na lógica econômica [recurso eletrônico]: desenvolvimento, aceleração e direitos fundamentais. Itajaí: UNIVALI; FAPESC, 2012. p, 24.
} 
Revista Eletrônica de Direito Processual - REDP.

Rio de Janeiro. Ano 13. Volume 20. Número 1. Janeiro a Abril de 2019

Periódico Quadrimestral da Pós-Graduação Stricto Sensu em Direito Processual da UERJ

Patrono: José Carlos Barbosa Moreira (in mem.). ISSN 1982-7636. pp. 55-81

www.redp.uerj.br

suas obrigações que não reflete sobre as consequências de suas ações, apenas segue o fluxo orientado por determinações superiores ${ }^{70}$.

Os resultados (ou fins) são aqueles que merecem protagonismo. Aliás, em nome deste processo penal para resultados (leia-se condenações) é que invoca-se a velocidade e eficiência. O viés econômico no qual se pauta o processo penal eficiente, em que os fins justificam os meios, enxerga as formas processuais ${ }^{71}$ somente como justificadas quando não demonstrarem óbices ao exercício do poder punitivo ${ }^{72}$. Tal como ensina $\operatorname{Casara}^{73} \mathrm{o}$ eficientismo é um modo de racionalizar o processo penal para transformá-lo em procedimento mais célere e menos custoso.

No processo penal do espetáculo, os fins justificam os meios, não causa surpresa, portanto, os ataques de parcela da magistratura ao princípio da presunção de inocência, apontado como uma das causas da impunidade. ${ }^{74}$

O medo é o produto vendido pela sensação constante de risco a partir da qual se promove a dinâmica da eficiência. Para Bizzotto ${ }^{75}$ atualmente se pode falar em uma cultura do medo, na qual o comportamento humano - a existência humana - tem se definido a partir do próprio medo. Reproduz-se com base na estabelecida cultura do medo, táticas de manipulação deste e sua consequente disseminação. Estratégias que, em se tratando de processo penal, acabam por disseminar a sensação de insegurança, de impunidade, de violência, para que se possa favorecer interesses políticos, sociais ou econômicos, como por exemplo para promover mudanças legislativas mais repressivas ${ }^{76}$.

A política criminal passa a atender aqueles setores que para a opinião pública se encontram mais ameaçados. Não se orienta nos ensinamentos clássicos acerca dos bens jurídicos construídos pela dogmática penal, mas buscam a proteção do bem estar. Adota bens jurídicos universais que descrevem-se de maneira vaga, a fim de que se justifique

\footnotetext{
${ }^{70}$ Id. p, 26.

${ }^{71}$ Formas como garantia e limite de poder. LOPES JR., Aury. Direito processual penal. 11. ed. São Paulo: Saraiva. p, 154.

${ }^{72}$ CASARA, Rubens R. R. Processo penal do espetáculo: ensaios sobre o poder penal, a dogmática e o autoritarismo na sociedade brasileira. $1^{\mathrm{a}}$ ed. Florianópolis: Empório do Direito, 2015. p, 138.

${ }^{73}$ Id. p, 140.

${ }^{74}$ CASARA, Rubens R. R, Processo Penal do Espetáculo: Ensaios sobre o poder penal, a dogmática e o autoritarismo na sociedade brasileira. $1^{a}$ ed. Florianópolis: Empório do Direito, 2015. P: 13

${ }^{75}$ BIZZOTTO, Alexandre. Op. cit. p, 98.

${ }^{76}$ Id. p, 99.
} 
Revista Eletrônica de Direito Processual - REDP.

Rio de Janeiro. Ano 13. Volume 20. Número 1. Janeiro a Abril de 2019

Periódico Quadrimestral da Pós-Graduação Stricto Sensu em Direito Processual da UERJ

Patrono: José Carlos Barbosa Moreira (in mem.). ISSN 1982-7636. pp. 55-81

www.redp.uerj.br

qualquer intervenção penal ${ }^{77}$. A técnica legislativa da eficiência é a construção de tipos penais que protejam abstrações jurídicas, crimes de perigo, que segundo Hassemer ${ }^{78}-\mathrm{em}$ sua maioria crimes de perigo abstrato - se basta na suficiente demonstração do ato que o legislador descreveu como perigoso.

A expansão do controle penal como expediente de combate ao medo face aos riscos é uma solução incerta. Para retomar o pensamento de $\mathrm{Ost}^{79}$, fica claro que a ordem social não será edificada quando se baseia em processos mais repressivos. Ao contrário, não parece se sustentar que uma sociedade possa ser duradoura quando lastreada por uma política pautada na "defesa social". Intervenções de urgência na intenção de produzir resultados mais céleres acabam por mitigar direitos fundamentais.

É tão evidente esta mitigação de direitos fundamentais que atinge o Direito Processual Penal, que admite o uso de material probatório sem que este tenha sido recolhido na observância do devido processo legal.

O julgador que se deixa convencer por uma prova obtida em contrariedade aos ditames legais e constitucionais e, portanto, ilícita, terá a sua decisão maculada, por mais que tente se valer de pseudo-fundamentações que venham a esconder a verdadeira causa de seu convencimento.

Conforme adverte Marrafon, "uma vez tomada a decisão, o resto é justificação argumentativa, especialmente quando se está diante de um justiceiro que quer preservar a legalidade violando a legalidade" $" 80$.

Toda essa inobservância a preceitos constitucionais do processo penal acarreta como assevera Gloeckner ${ }^{81}$ - na transformação da eficiência num conceito jurídicovalorativo que permite a desformalização material do processo penal. Essa desformalização compõe um conjunto de elementos que, pautados no eficientismo, assombram o futuro do processo penal.

\footnotetext{
${ }^{77}$ HASSEMER, Winfried. Op. cit., p, 190.

${ }^{78}$ Id. p, 191.

${ }^{79}$ OST, François. Op. cit., p, 358.

80 MARRAFON, Marco Aurélio. Constituição e Poder, Vol. 1: decisão constitucional, filosofia da linguagem e direito. $1^{\mathrm{a}}$ ed. Florianópolis: Empório do Direito, 2016. p, 47.

${ }^{81}$ GLOECKNER, Ricardo Jacobsen. Nulidades no processo penal: introdução principiológica à teoria do ato processual irregular. $2^{\mathrm{a}}$ ed., Editora Juspodivm. 2015, p. 507.
} 
Revista Eletrônica de Direito Processual - REDP.

Rio de Janeiro. Ano 13. Volume 20. Número 1. Janeiro a Abril de 2019

Periódico Quadrimestral da Pós-Graduação Stricto Sensu em Direito Processual da UERJ

Patrono: José Carlos Barbosa Moreira (in mem.). ISSN 1982-7636. pp. 55-81

www.redp.uerj.br

A partir desta ordem de eficiência retornam (ou talvez nunca se tenha afastado) ao processo penal princípios inquisitoriais que satisfazem arbitrariedades, como a busca da verdade a qualquer custo; A verdade substancial ou real.

A verdade real para o processo penal é um mito construído pelo substancialismo inquisitório. Lopes Jr. esclarece que a busca pela verdade real, ou ao menos a mais material e consistente, surge no processo penal quando este não guardava limites, quando eram permitidos abusos nas atividades de busca, admitindo-se inclusive a tortura ${ }^{82}$.

Diante deste quadro, no qual o magnetismo e a repetição do discurso míticoprocessual parecem revelar que os mitos processuais penais foram construídos por e para uma sociedade acostumada com o autoritarismo, a superação da mitologia autoritária exige a compreensão da Constituição Federal e de suas promessas, até então descumpridas ${ }^{83}$.

Este "mito" está diretamente ligado à "estrutura do sistema inquisitorial, com o interesse público (cláusula geral que serviu de argumento para as maiores atrocidades), com sistemas políticos autoritários, com a busca de uma verdade a qualquer custo; e com a figura do juiz-ator (inquisidor)" ${ }^{" 84}$.

Em nome dessa tal verdade aceita-se o inaceitável, as mais absurdas violações a direitos e garantias são permitidas para que se produza o resultado (em se tratando do processo penal do eficientismo, eliminar a criminalidade). A eficiência necrosa os laços de proteção que se possui diante do poder estatal, transforma-se em uma concepção funcionalista do processo penal ${ }^{85}$.

O Direito Penal eficaz, para Hassemer, utiliza-se de dois critérios dogmáticos principais, a funcionalidade da administração da justiça penal e o critério metódico da ponderação de bens. Quanto ao primeiro, trata-se de uma inversão sistemática autêntica, vez que consagra injustificadamente a funcionalidade da administração da justiça penal como um princípio normativo básico, que mancha o contraste entre segurança jurídica e

\footnotetext{
${ }^{82}$ LOPES JR., Aury. O problema da "verdade" no processo penal. In: GRINOVER, Ada Pellegrini, et all. Verdade e prova no processo penal: Estudos em homenagem ao professor Michele Taruffo. Coordenador Flávio Cardoso Pereira. 1 ed. Brasília, DF: Gazeta Jurídica,2016. p, 67.

${ }^{83}$ Casara, Rubens R.R. Mitologia Processual Penal. São Paulo: Saraiva, 2015. p, 25.

${ }^{84}$ LOPES JR., Aury. O problema da "verdade" no processo penal. In: GRINOVER, Ada Pellegrini, et all. Verdade e prova no processo penal: Estudos em homenagem ao professor Michele Taruffo. Coordenador Flávio Cardoso Pereira. 1 ed. Brasília, DF: Gazeta Jurídica,2016. p, 68.

${ }^{85}$ GLOECKNER, Ricardo Jacobsen. Op. cit. p, 509.
} 
Revista Eletrônica de Direito Processual - REDP.

Rio de Janeiro. Ano 13. Volume 20. Número 1. Janeiro a Abril de 2019

Periódico Quadrimestral da Pós-Graduação Stricto Sensu em Direito Processual da UERJ

Patrono: José Carlos Barbosa Moreira (in mem.). ISSN 1982-7636. pp. 55-81

www.redp.uerj.br

justiça, investigação da verdade e proteção dos direitos do imputado, eficácia e formalização ${ }^{86}$.

Quanto ao segundo, o critério da ponderação entre bens - nos casos de necessidade -, a ponderação de interesses legitima a intervenção em direitos e princípios que são a base de nossa cultura jurídica. Conclui Hassemer que, tal "critério dogmático" funciona como instrumento contundente para o aumento da "eficácia" do Direito Penal ${ }^{87}$.

Afinal de contas, não é essa a tendência atual, um processo penal que em direção ao futuro eficientista rompe com as barreiras garantidoras de limites do poder punitivo? Mais ainda, a pergunta que se faz é: pode ser chamado de direito processual penal este procedimento subtraído de suas bases fundantes?

Não é demais reafirmar que efetividade e eficiência não se confundem. Um processo penal efetivo é somente aquele que obedece aos ditames constitucionais e convencionais. A garantia de limites ao poder punitivo é a essência do processo penal, não havendo processo quando não respeitados direitos fundamentais.

\section{CONSIDERAÇÕES FINAIS}

O paradigma da questão da ilicitude probatória se insere em uma complexa compreensão do processo penal, que é muito mais do que um instrumento de composição do litígio penal mas, sobretudo, um instrumento político de participação, com maior ou menor intensidade, conforme evolui o nível de democratização da sociedade ${ }^{88}$.

É necessário que os regramentos probatórios sejam concebidos a partir de uma compreensão do papel do processo em um democracia constitucional.

Sendo uma marca fundamental de uma democracia substancial os direitos do cidadão diante do Estado, lógicas utilitaristas, não podem ser legitimadas, sob pena de representar um alto custo a ser pago.

\footnotetext{
${ }^{86}$ HASSEMER, Winfried. Op. cit., p, 194.

${ }^{87}$ Id. p, 195.

${ }^{88}$ PRADO, Geraldo. Sistema Acusatório: A conformidade constitucional das leis penais. Rio de Janeiro: Lumen Juris, 2001. P. 50.
} 
Revista Eletrônica de Direito Processual - REDP.

Rio de Janeiro. Ano 13. Volume 20. Número 1. Janeiro a Abril de 2019

Periódico Quadrimestral da Pós-Graduação Stricto Sensu em Direito Processual da UERJ

Patrono: José Carlos Barbosa Moreira (in mem.). ISSN 1982-7636. pp. 55-81

www.redp.uerj.br

A necessidade democrática de atuação estatal pautada em regras que a limitem, é nota característica de qualquer composição estatal que não tolere o totalitarismo de uma atuação ilimitada e imprevisível dos agentes públicos.

As garantias processuais se inserem no quadro de direitos fundamentais e não podem ceder ainda que em nome de pretensas práticas que visem o bem comum.

Os direitos fundamentais constituem-se em cláusulas pétreas protetivas do conteúdo essencial, núcleo intangível da $\mathrm{CF}$, cuja compreensão constitucional e convencional, aplicação e efetivação estão a cargo dos sujeitos, independentemente das instituições a que pertençam ${ }^{89}$.

É tarefa de todos a defesa dos direitos fundamentais, principalmente daqueles que ocupam a posição de garantes das regras do jogo processual.

Não se pode admitir a prática de atos ilegais, o que, como destaca Miglino, remonta suas origens, ao nascedouro da Democracia: "A importância dada pelos atenienses à administração da Justiça é o corolário lógico de um princípio: é vão estabelecer normas se não se pode punir sua violação" 90 .

Portanto, argumentos imunizadores da ilicitude, como "ilegitimidade" da prova, como "bem comum", "verdade real", nada mais fazem do que revelar a matriz autoritária que insiste em guiar o nosso processo penal.

Uma tentativa vã de esconder a ilegalidade dos atos praticadas e, pior, ainda revesti-las com ilusórios adereços salvacionistas, travestindo práticas ilegais e inconstitucionais em medidas necessárias ao bem comum, violando direitos e garantias individuais sob a falsa promessa de defesa dos direitos coletivos.

O devido processo legal só é devido quando legal e só é legal quando for devido, portanto, a ilegalidade não pode coabitar com esta garantia fundamental e tolerar esta prática representa uma perigosa abertura para um fértil terreno de arbitrariedades.

Em uma era democrática os valores legalmente insculpidos devem ser defendidos. O fascismo não precisa de uma "marcha" espetacular sobre alguma capital para se instalar, basta-lhe uma decisão aparentemente anódina de tolerar um tratamento ilegal dos inimigos.

\footnotetext{
${ }^{89}$ GIACOMOLLI, Nereu José. O Devido Processo Penal: abordagem conforme a Constituição Federal e o Pacto de São José da Costa Rica. São Paulo: Atlas, 2014. p, 15.

${ }^{90}$ MIGLINO, Arnaldo. As Cores da Democracia. Tradução Fauzi Hassan Chouckr. $2^{\mathrm{a}}$ ed. Florianópolis: Empório do Direito, 2016. p, 62.
} 
Revista Eletrônica de Direito Processual - REDP.

Rio de Janeiro. Ano 13. Volume 20. Número 1. Janeiro a Abril de 2019

Periódico Quadrimestral da Pós-Graduação Stricto Sensu em Direito Processual da UERJ

Patrono: José Carlos Barbosa Moreira (in mem.). ISSN 1982-7636. pp. 55-81

www.redp.uerj.br

Eis por que podemos encontrar sinais de advertência ameaçadores em situações de paralisia política frente a uma crise, conservadores ameaçados em busca de aliados mais duros, dispostos a prescindir do devido processo e do império da lei e que buscam apoio de massas mediante a demagogia nacionalista e racista ${ }^{91}$.

\section{REFERÊNCIAS BIBLIOGRÁFICAS:}

ARMENTA DEU, Teresa. A prova ilícita: um estudo comparado. 1. ed. São Paulo: Marcial Pons, 2014.

BADARO, Gustavo. Processo penal. $4^{\mathrm{a}}$ ed. rev. atual. e ampl. São Paulo: Editora Revista dos Tribunais, 2016.

BERNARDES, Marcelo Di Rezende. O princípio constitucional da motivação das decisões judiciais. Fragmentos de Cultura, Goiânia, v. 23, n. 2, p. 195-206, abr/jun. 2013.

BINDER, Alberto M. O Descumprimento das formas processuais: elementos para uma crítica da teoria unitária das nulidades no processo penal. Rio de Janeiro: Editora Lumen Juris, 2003.

BIZZOTO, Alexandre. A mão invisível do medo e o pensamento criminal libertário. $1^{\text {a }}$ ed. Florianópolis: Empório do Direito. 2015.

BOBBIO, Norberto. A era dos direitos. Tradução de Carlos Nelson Coutinho. Rio de Janeiro: Elsevier, 2004.

BRASIL, Exposição de Motivos ao Código de Processo Penal Brasileiro.

CARVALHO, Amilton Bueno de. Eles, os juízes criminais, vistos por nós, os juízes criminais. Rio de janeiro: Lumen Juris, 2011.

CASARA, Rubens R. R. Processo penal do espetáculo: ensaios sobre o poder penal, a dogmática e o autoritarismo na sociedade brasileira. $1^{\text {a }}$ ed. Florianópolis: Empório do Direito, 2015.

CASARA, Rubens R.R. Mitologia Processual Penal. São Paulo: Saraiva, 2015.

\footnotetext{
91 MARTInS, Rui Cunha. A Hora dos Cadáveres Adiados: Corrupção, Expectativa e Processo. São Paulo: Atlas, 2013. P: 31
} 
Revista Eletrônica de Direito Processual - REDP.

Rio de Janeiro. Ano 13. Volume 20. Número 1. Janeiro a Abril de 2019

Periódico Quadrimestral da Pós-Graduação Stricto Sensu em Direito Processual da UERJ

Patrono: José Carlos Barbosa Moreira (in mem.). ISSN 1982-7636. pp. 55-81

www.redp.uerj.br

COUTINHO, Jacinto Nelson de Miranda. Efetividade do Processo Penal e Golpe de

Cena: um problema às reformas processuais. 2015. Disponível em: http://emporiododireito.com.br/efetividade-do-processo-penal-e-golpe-de-cena-umproblema-as-reformas-processuais-por-jacinto-nelson-de-miranda-coutinho/. Acesso em Jul 2017.

COUTINHO, Jacinto Nelson de Miranda. Glosas ao Verdade, Dúvida e Certeza de Francesco Carnelutti para os Operadores do Direito. In: Revista de Estudos Criminais Ano 4 No 14. Sapucaia do Sul: Notadez, 2004.

CORDERO, Franco. Procedimiento Penal. Trad. Jorge Guerrero. Editorial Temis: Santa Fe de Bogotá, 2000.

EBERHARDT, Marcos. Provas no processo penal: análise crítica, doutrinária e jurisprudencial. Porto Alegre: Livraria do Advogado Editora, 2016. p, 52.

GAUER, Ruth Maria Chittó. Conhecimento e aceleração (mito, verdade, tempo). In: GAUER, Ruth Maria Chittó (Org.). A Qualidade do Tempo: para além das aparências históricas. Rio de Janeiro: Lumen Juris, 2004.

GAUER, Ruth Maria Chitto. Constituição e Cidadania. Porto Alegre: Livraria do Advogado, 2014.

GIACOMOLLI, Nereu. O devido processo penal: abordagem conforme a Constituição

Federal e o Pacto de São José da Costa Rica. $2^{a}$ ed. São Paulo: Atlas, 2015.

GIACOMOLLI, Nereu. Reformas (?) do processo penal: considerações críticas. Rio de Janeiro: Editora Lumen Juris. 2008.

GOLDSCHIMIDT, James Paul. Princípios gerais do processo penal, Tradução: Hiltomar Martins de Oliveira. Belo Horizonte: Líder, 2002.

GLOECKNER, Ricardo Jacobsen. Nulidades no processo penal: introdução principiológica à teoria do ato processual irregular. $2^{\mathrm{a}}$ ed., Editora Juspodivm. 2015.

HASSEMER, Winfried. El destino de los derechos del ciudadano en un derecho penal eficaz. Estudios Penales y Criminológicos, vol. XV (1992). Cursos e Congresos $n^{\circ} 71$ Servizo de Publicacións da Universidade de Santiago de Compostela. ISBN 847191-866-8, pp. 182-198.p, 189.

KAFKA, Franz. O processo. 5. Ed. São Paulo: Martin Claret, 2011. 
Revista Eletrônica de Direito Processual - REDP.

Rio de Janeiro. Ano 13. Volume 20. Número 1. Janeiro a Abril de 2019

Periódico Quadrimestral da Pós-Graduação Stricto Sensu em Direito Processual da UERJ

Patrono: José Carlos Barbosa Moreira (in mem.). ISSN 1982-7636. pp. 55-81

www.redp.uerj.br

KHAlED JR., Salah Hassan A Busca da Verdade no Processo Penal: Para Além da

Ambição Inquisitorial. São Paulo: Atlas, 2013.

LOPES JR., Aury. Direito processual penal. 11. ed. São Paulo: Saraiva, 2014.

LOPES JR., Aury. O problema da "verdade" no processo penal. In: GRINOVER, Ada

Pellegrini, et all. Verdade e prova no processo penal: Estudos em homenagem ao professor Michele Taruffo. Coordenador Flávio Cardoso Pereira. 1 ed. Brasília, DF:

Gazeta Jurídica,2016. p, 67.

MARRAFON, Marco Aurélio. Constituição e Poder, Vol. 1: decisão constitucional, filosofia da linguagem e direito. $1^{\mathrm{a}}$ ed. Florianópolis: Empório do Direito, 2016.

MARTINS, Rui Cunha. A Hora dos Cadáveres Adiados: Corrupção, Expectativa e Processo. São Paulo: Atlas, 2013.

MARTINS, Rui Cunha. O Ponto Cego do Direito, The Brazilian Lessons. Rio de Janeiro: Lumen Juris, 2010.

MiglinO, Arnaldo. As Cores da Democracia. Tradução Fauzi Hassan Chouckr. $2^{\mathrm{a}}$ ed. Florianópolis: Empório do Direito, 2016.

MUÑOZ CONDE, Francisco. De la prohibición de autoincriminación al derecho procesal penal del enemigo. In: Estudos em homenagem ao Prof. Doutor Jorge de Figueiredo Dias / coord. por Manuel da Costa Andrade, Maria João Antunes, Susana Aires de Sousa, Vol. 3, 2009 (Direito Penal (Cont.)), ISBN 978-972-32-17933, págs. 1013 - 1040. Boletim da Faculdade de Direito, Stvdia Ivridica 100, Ad Honorem - 5, Universidade de Coimbra, Coimbra Editora. p, 1014.

OST, François. O tempo do direito. Bauru, SP: Edusc, 2005.

POZZEBON, Fabrício Dreyer de Avila. O direito fundamental à motivação no processo penal como corolário de outras garantias constitucionais. Direitos Fundamentais e Justiça Nº8. Jul/Set. 2009.

PRADO, Geraldo. Sistema Acusatório: A conformidade constitucional das leis penais.

Rio de Janeiro: Lumen Juris, 2001.

PRADO, Geraldo. Limites às interceptações telefônicas e a jurisprudência do Superior Tribunal de Justiça. $2^{\text {a }}$ ed. Rio de Janeiro: Editora Lumen Juris. 2006. 
Revista Eletrônica de Direito Processual - REDP.

Rio de Janeiro. Ano 13. Volume 20. Número 1. Janeiro a Abril de 2019

Periódico Quadrimestral da Pós-Graduação Stricto Sensu em Direito Processual da UERJ

Patrono: José Carlos Barbosa Moreira (in mem.). ISSN 1982-7636. pp. 55-81 www.redp.uerj.br

PRADO, Geraldo. Prova penal e sistema de controles epistêmicos: a quebra da cadeia de custódia das provas obtidas por métodos ocultos. 1 ed. São Paulo: Marcial Pons, 2014.

ROSA, Alexandre Morais da e MARCELLINO JR, Julio Cesar. O processo eficiente na lógica econômica [recurso eletrônico]: desenvolvimento, aceleração e direitos fundamentais. Itajaí: UNIVALI; FAPESC, 2012.

ROSA, Alexandre Morais da. Guia Compacto do Processo Penal conforme a Teoria dos Jogos. 1 Ed. Rio de Janeiro: Lumen Juris, 2013.

SARLET, Ingo Wolfgang. A eficácia dos direitos fundamentais. 11 ed., revista e atualizada, Porto Alegre: Livraria do Advogado Editora, 2012.

SARLET, Ingo Wolfgang; MARINONI, Luiz Guilherme; MITIDIERO, Daniel. Curso de Direito Constitucional. $6^{\text {a }}$ ed., revista e atualizada. São Paulo: Saraiva, 2017.

ZAFFARONI, Eugênio Raul. Poder Judiciário: Crises, acertos e desacertos. Trad: Juarez Tavares. São Paulo: Revista dos Tribunais, 1995 